\title{
A conceptual model for evaluation of synergies in mergers and acquisitions: A critical review of the literature
}

\author{
G.V.M. Kode, J.C. Ford and M.M. Sutherland* \\ Wits Business School, \\ PO Box 98, Wits 2050, Republic of South Africa \\ sutherland.m@wbs.wits.ac.za \\ Received January 2003
}

\begin{abstract}
The vast majority of mergers and acquisitions rely on synergies in the value creation process. Only a small proportion of mergers and acquisitions are undertaken for non-synergistic reasons. Many mergers and acquisitions never achieve the pre-deal successes that are used to motivate and justify the payment of huge premiums over the stand-alone value of the target companies. Because synergies are used to justify the payment of premiums, executive management, need to fully understand how to evaluate synergies.
\end{abstract}

This model building exercise has enabled the development of an integrated model for the evaluation of synergies that uses the best practices identified from the writings of the authors under review. The model, therefore, provides academics and executive management with a framework for better understanding synergies and some techniques to ensure the realisation of productive synergies in the implementation of mergers and acquisitions.

*To whom all correspondence should be addressed.

\section{Introduction}

From January 1990 to June 1997, 96020 companies in the world came under new ownership through mergers and acquisitions worth \$3.9 trillion (Lajoux, 1997). In 1999 alone, it is estimated that worldwide merger and acquisition activity rose by over one third from 1998 levels to more than \$3.4 trillion (The Economist, 2000). Marks and Mirvis (1997) estimate that more than three-quarters of these corporate mergers and acquisitions failed to achieve the predeal forecasts for these transactions. The Economist (2000) reports that a KPMG paper estimates that more than half of mergers and acquisitions destroy shareholder value.

Many acquisitions fail to create shareholder value for the buyer, not because of poor valuation techniques but through either a failure to evaluate synergies at all or through payment of excessive premiums relative to the potential synergies that could be realised from the merger. The valuation of uncertain future benefits such as synergies is difficult and this part of the overall valuation, is therefore, often not performed at all or inadequately addressed (Rappaport, 1998). Acquirers also often pay a premium over the stand-alone value of the target company based on the existence of these synergies. A failure to understand, define and value these synergies results in the destruction of shareholder value and the loss of the 'acquisition game' (Sirower, 1997). Since the value of the synergies represents the maximum premium that a buyer can afford to pay over the stand-alone value of the target (Rappaport, 1998), a comprehensive understanding of synergies, a method to evaluate and to apportion them between buyer and seller and a means to ensure they are actually achieved is crucial.

Value is created through acquisitions from buying cheap, managing the target better than the current managers or through the creation or enhancement of deeper relationships and synergies. With an increasingly competitive market for potential targets, buying cheap is very difficult. Replacing management often occurs through corporate raiding, which was more common in the 1980s (Rappaport, 1998) and, although still important, is not the focus of this research. The analysis and evaluation of synergies and how this relates to the payment of acquisition premiums is, however, directly within the ambit of this study.

\section{Aims}

The article aims to assess the significance of synergy identification and evaluation in the pre-deal stage of mergers and acquisitions. It also looks at the extent to which synergy evaluation plays a role in determining the premium paid for an acquisition over the market value of the target company. The existence and extent of planning for synergy realisation and for functional integration of the merged entities will be analysed in relation to the value creation process. This article will provide executive management involved in mergers and acquisitions with a conceptual framework for understanding the value creation process and to apply the concepts involved to enhance shareholder value creation. Without a proper analysis of synergies and a 
method to evaluate them, management will be hard pressed to deliver on their value creation mandate.

\section{Analytical method}

The analysis was undertaken in the form of a documentary review via content analysis (Babbie, 1998). It consisted of a detailed scanning of the literature on the subject to identify common threads and to crystallise the thinking around it. The research was necessarily qualitative and aimed at producing theoretical constructs (Miles \& Humberman, 1994). 'Qualitative research is more frequently concerned to identify concepts in the data and to develop a theory which incorporates them' (Walker, 1985:178). The documentary review methodology provided this qualitative data for the research. Current techniques and methods already documented by authors in literary works, journals, press writings and other public sources were surveyed and common threads identified and crystallised.

Content analysis is a more sophisticated research method than merely counting the occurrence of constructs and this is achieved through the development of a system of analysis for the capture and presentation of the data (Zikmund, 1997). The constructs that emerged from the literature review were directed to answering the research questions (Bailey, 1982). This set of mutually exclusive and exhaustive categories (i.e. constructs) was developed and used to analyse the literature. The occurrence of each such construct within the works sampled was observed. The recording unit was the theme inherent in the constructs and the system of enumeration was whether the theme was considered by the particular author or not (Bailey, 1982). Thus, a meta-analysis of the literature was conducted.

\section{Limitations of Approach}

As a result of the fact that this research was conducted solely through an analysis of literature constructs, the findings have not been empirically validated. Due to the judgement sampling techniques, biases may have been present (Zikmund, 1997).

\section{Literature review}

This research is a holistic consideration of particular types of mergers and acquisitions that attempt to create something greater than the sum of the previously independent parts. With this type of combination, the focus is on the strategies and processes required for the identification and attainment of true and productive synergies (Marks \& Mirvis, 1997).

Strategic fit is often used as a generic term for the collective synergies created by a merger or an acquisition. Strategic fit is, however, only able to add value if the acquisition benefits the key value drivers of the two firms together as opposed to them apart. Mergers and acquisitions are, therefore, driven by this promise and it is the pursuit of this promise in the value creation process that is the subject of this research. Sirower (1997:6) provides the most succinct definition of synergies when he defines '... synergy as increases in competitiveness and resulting cash flows beyond what the two companies are expected to accomplish independently'. When this definition is read within the framework of synergies in relation to premiums paid and to the shareholder value creation process, the definition captures the essence of synergies and all that synergies try to achieve.

Marks and Mirvis (1997), Haspeslagh and Jemison (1991) and Campbell and Goold (1998) add to this definition by considering synergies with respect to a type of collective value creation process by which competitive advantage is increased. 'Synergy occurs when capabilities transferred between firms improve a firm's competitive position and consequently its performance' (Haspeslagh \& Jemison, 1991:22).

\section{Reasons for doing mergers and acquisitions.}

Mergers and acquisitions are carried out for a variety of reasons which can be categorised as synergistic, nonsynergistic and/or strategic. Non-synergistic combinations can be described as non-core diversification transactions and strategic combinations are done for reasons such as eliminating competition, securing a supply or distribution line or preventing a competitor from acquiring the target. The reasons given in the literature for carrying out mergers and acquisitions are:

- Industry specific requirements (Harpeslagh \& Jemison, 1991)

- Globalization leading to scale requirements (Galpin \& Herndon, 1999)

- $\quad$ Speed and cost considerations of growth (Marks \& Merivs, 1997)

- $\quad$ Product and service range expansion (Galpin \& Herndon, 1999)

- Risk reduction and diversification (Rappaport, 1998)

- Leverage of core competencies or technology changes (Slusky \& Caves, 1991).

All of the above primary reasons for doing mergers and acquisitions have synergistic elements to them.

\section{Reasons for the failure of mergers and acquisitions}

Table 1 sets out the various reasons espoused for the failings of mergers and acquisitions and shows the extent of the support for these failings in the literature under review. 
Table 1: Reasons for the failures of mergers and acquisitions

\begin{tabular}{|c|c|c|c|c|c|c|c|}
\hline & $\begin{array}{l}\text { No plan to } \\
\text { integrate } \\
\text { and integra- } \\
\text { tion } \\
\text { problems }\end{array}$ & $\begin{array}{c}\text { Failure to } \\
\text { understand the } \\
\text { acquisition } \\
\text { game formulae }\end{array}$ & $\begin{array}{c}\text { Biases in } \\
\text { favour of } \\
\text { synergies and } \\
\text { its conse- } \\
\text { quences }\end{array}$ & $\begin{array}{l}\text { Slow pace of } \\
\text { integration }\end{array}$ & $\begin{array}{c}\text { Inadequate } \\
\text { due diligence, } \\
\text { no strategy, } \\
\text { poor } \\
\text { preparation } \\
\text { and undue } \\
\text { haste } \\
\end{array}$ & $\begin{array}{l}\text { Loss of } \\
\text { value } \\
\text { through } \\
\text { failure of } \\
\text { current } \\
\text { strategic } \\
\text { plans } \\
\end{array}$ & $\begin{array}{l}\text { Payment of } \\
\text { too high an } \\
\text { acquisition } \\
\text { premium }\end{array}$ \\
\hline $\begin{array}{c}\text { Bijlsma- } \\
\text { Frankema } \\
(2001)\end{array}$ & $\checkmark$ & & & & & & \\
\hline $\begin{array}{l}\text { Campbell \& } \\
\text { Goold (1998) }\end{array}$ & $\checkmark$ & & $\checkmark$ & & & & \\
\hline $\begin{array}{l}\text { Copeland, Koller } \\
\& \text { Murrin (1990) }\end{array}$ & $\checkmark$ & & $\checkmark$ & $\checkmark$ & $\checkmark$ & & $\checkmark$ \\
\hline $\begin{array}{l}\text { Eccles, Lane \& } \\
\text { Wilson (1999) }\end{array}$ & & & $\checkmark$ & & & & $\checkmark$ \\
\hline $\begin{array}{l}\text { Galpin \& } \\
\text { Herndon (1999) }\end{array}$ & $\checkmark$ & & & & $\checkmark$ & $\checkmark$ & \\
\hline $\begin{array}{l}\text { Haunschild } \\
(1994)\end{array}$ & & & & & & & $\checkmark$ \\
\hline $\begin{array}{l}\text { Haspeslagh \& } \\
\text { Jemison (1991) }\end{array}$ & $\checkmark$ & & & $\checkmark$ & $\checkmark$ & & $\checkmark$ \\
\hline $\begin{array}{l}\text { Horwitz et al } \\
(2002)\end{array}$ & $\checkmark$ & & & & & & \\
\hline Howell (1970) & $\checkmark$ & & & & & $\checkmark$ & \\
\hline $\begin{array}{l}\text { Jemison \& Sitkin } \\
(1986)\end{array}$ & $\checkmark$ & & & & $\checkmark$ & & \\
\hline Key (1989) & & & & & & & $\checkmark$ \\
\hline Lajoux (1997) & $\checkmark$ & & & $\checkmark$ & $\checkmark$ & & $\checkmark$ \\
\hline $\begin{array}{l}\text { Marks \& Mirvis } \\
\text { (1997) }\end{array}$ & $\checkmark$ & & & & $\checkmark$ & & $\checkmark$ \\
\hline Rappaport (1998) & & $\checkmark$ & & $\checkmark$ & & & $\checkmark$ \\
\hline Seyhun (1990) & & & & & & & $\checkmark$ \\
\hline Sirower (1997) & & $\checkmark$ & & $\checkmark$ & & $\checkmark$ & $\checkmark$ \\
\hline Zweig (1995) & $\checkmark$ & & $\checkmark$ & & & & $\checkmark$ \\
\hline $\begin{array}{l}\text { Frequency (out } \\
\text { of a total 15) }\end{array}$ & 11 & 2 & 4 & 5 & 6 & 3 & 11 \\
\hline
\end{tabular}

The literature clearly shows that the payment of too high an acquisition price and the lack of planning to integrate the organisations are the leading causes of failure. Both of these relate to unrealised synergies. Synergies can only be achieved or realised through post merger integration of both processes and people and, where a premium has been paid for the acquisition, the slower the integration the slower the realisation of synergies will be and the more expensive it will be to repay the premium paid (Lajoux, 1997). Horwitz, Anderssen, Bezuidenhout, Cohen, Kirsten, Mosoeunyane, Smith, Thole and van Heerden (2002) show that neglect of the 'soft' due diligence factors of cultural and human resource capabilities hampers transition and effective integration of the new entity. Bijlsma-Frankema (2001) examines the friction between the merging organisations and how best to minimise it.

\section{Synergy evaluation as a subsection of the merger process}

The identification and evaluation of synergies are crucially important because (1) there are no dress rehearsals for acquisitions, (2) all the premium is paid up front, (3) exit costs are often very high and (4) achieving synergies is analogous to starting up a new business. 'Adding synergy means creating value that not only does not yet exist but is not yet expected' (Sirower, 1997:21). If the strategy is to create value, then the purchase price must reflect the level of risk and probability of achieving the envisaged synergies. In this way, the reasons for doing the deal and the reasons behind the failings of transactions are interrelated and directed at the same end.

Synergy evaluation is an important aspect of mergers and acquisitions and must necessarily be dealt with somewhere in the process. A consideration of various approaches is appropriate for executive management to achieve a greater understanding of the challenges that synergies pose in mergers and acquisitions.

Four different broad types of merger and acquisition processes were identified from the literature. The categories are as follows:

a) Synergy Evaluation as the Basis for each Stage of the Process - this is a process in which synergy 
identification and evaluation forms the basis for the process itself and synergies are considered at each stage of the process (Campbell \& Goold, 1998; Eccles, Lane \& Wilson, 1999; Marks \& Mirvis, 1997; Rappaport, 1998; Sirower, 1997). At each stage of the process, the synergistic interrelationships have to be converted into strategies that can be practically implemented. 'The more an acquisition depends upon synergistic interrelationships, the greater is the need to develop a post-merger integration blueprint beforehand' (Rappaport, 1998:137).

b) Focus Entirely on Integration and Implementation of the Combination to Achieve Synergies - here no specific stage was dedicated to synergies although the integration process itself was isolated as the only satisfactory method for achieving synergies (Eienhardt \& Galunic, 2000; Howell, 1970; Lajoux, 1997). Lajoux (1997) does not distinguish synergy evaluation as a separate and distinct phase of the merger process but reduces the success of all mergers, and hence the achievement of synergies, as being inextricably related to the integration process.

c) One Single Distinct and Separate Synergy Evaluation Stage in the Process - a process that dedicated only a single stage in the process to synergies (Galpin \& Herndon, 1999; Haspeslagh \& Jemison, 1991).

d) No Specific Synergy Evaluation Stage - a process in which synergy identification and evaluation was not isolated as a separate stage in the merger process but was addressed in an ad hoc manner during the process (Jemison \& Sitkin, 1986; Key, 1989).

By far the most widely applied and advocated category of approaches is where synergy evaluation is the basis of the entire process. The second most cited approach concentrated on integration as the path to the realisation of productive synergies. There are merits to all four approaches and the ultimate approach adopted for any particular combination should be determined with reference to the extent to which synergistic interrelationships form the basis for the decision.

\section{The significance of synergy evaluation in the value creation process}

Since large acquisition premiums are being paid for target companies in excess of their stand-alone values, it stands to reason that there must be some relationship between the size of the premiums and the value of the anticipated synergies. Even where the premium is paid to achieve control over the target company, there can be no justification for the capital lay out of a premium if there is no prospect of earning back the premium through the exploitation of synergistic opportunities. There must, therefore, also be a mechanism for the evaluation, as opposed to the valuation, of these synergies relative to the acquisition premium. Sirower defines the merger or takeover premium as 'the amount the acquiring firm pays for an acquisition that is above the preacquisition price of the target company ... the acquisition premium represents the expectation of synergy in a corporate combination' (Sirower, 1997:46-47).

The literature delivered evidence of three broad methods for analysing the relationship between synergies and the payment of an acquisition premium.

- Eight of the authors related the present value of the expected synergies from the transaction to the anticipated future cash flow improvements resulting from the acquisition (Eccles, Lane \& Wilson, 1999; Haunschild, 1994; Lajoux, 1997; Marks \& Mirvis, 1997; Rappaport, 1998; Sirower, 1997; Varaiya, 1987; Zweig, 1995).

- Seven of the authors also used some form of breakeven analysis to determine the point at which shareholder value is either created or destroyed (Eccles, Lane \& Wilson, 1999; Haunschild, 1994; Lajoux, 1997; Marks \& Mirvis, 1997; Rappaport, 1998; Sirower, 1997; Varaiya, 1987).

- Six of the authors indicated an ancillary process was performed through an analysis of the value drivers of a synergistic transaction, an estimation of the increases in cash flow resulting from those drivers and then from that point, determining the value to be created by the combination (Campbell \& Goold, 1998; Galpin \& Herndon, 1999; Haspeslagh \& Jemison, 1991; Healy, Palepu \& Ruback, 1992; Howell, 1970; Rappaport, 1998).

Since the existence of potential paper synergies is the predeal justification for the payment of an acquisition premium, the realisation of tangible and productive synergies is the post-merger justification of the acquisition premium. Where the expected synergies do not exist or have not been captured, there is no justification for the premium and shareholder value, from the buyer's point of view, has been destroyed.

\section{Consequences of paying an acquisition premium}

'Paying a premium raises the asset base of the acquired firm and causes an immediate drop in profitability measures. Just to break even, the net income needs to increase to an amount that brings the return on assets back to pre-merger levels. Required synergy is the additional free cash flow that managers must bring in to accomplish this break-even target' (Sirower, 1997:51).

Where high premiums are paid, the value of synergies often have to be substantial to reach a break-even point and this is what Sirower (1997:51) describes as the 'synergy trap'. Once an acquirer has paid the premium, the acquirer then resorts to synergies to justify the premium. The most important concept for senior executives involved in mergers or acquisitions is that premiums translate directly into higher performance targets for the new combined entity. Many executives fail to make this crucial connection and most also view the value creation process as a long-term exercise, which is a fundamental misunderstanding of the effect that the payment of an acquisition premium has on future 
performance requirements.

The market assesses mergers and acquisitions on announcement and the share price movement at that time provides an indication of the anticipated value to be created by the deal. Rappaport (1998) suggests that there is evidence that the market is unbiased in its ability to misjudge transactions and therefore, that share price movements on the day of announcement are reliable barometers of future success. Where the premium paid exceeds the present value of the synergies, the selling shareholders will capture all the value created in the acquisition process (Rappaport, 1998).

Table 2 records the findings of this study into the consequences of paying an acquisition premium and demonstrates the relative importance with which these consequences are regarded by the various authors.

Table 2: Consequences of paying an acquisition premium

\begin{tabular}{|c|c|c|c|c|c|c|c|}
\hline & $\begin{array}{l}\text { Asset base is } \\
\text { raised } \\
\text { immediately }\end{array}$ & $\begin{array}{c}\text { Normal } \\
\text { profitability is } \\
\text { affected } \\
\text { because of } \\
\text { merger } \\
\text { distractions }\end{array}$ & $\begin{array}{c}\text { Pre-merger } \\
\text { income must be } \\
\text { sustained }\end{array}$ & $\begin{array}{c}\text { Market } \\
\text { punishes } \\
\text { buyer for } \\
\text { over-paying }\end{array}$ & $\begin{array}{l}\text { If synergies } \\
\text { equal } \\
\text { premium, } \\
\text { seller } \\
\text { captures all } \\
\text { the value }\end{array}$ & $\begin{array}{c}\text { Higher } \\
\text { perform- } \\
\text { ance targets } \\
\text { are set }\end{array}$ & $\begin{array}{c}\text { Synergies } \\
\text { must be } \\
\text { realised } \\
\text { quickly } \\
\text { because of } \\
\text { the present } \\
\text { value factor } \\
\text { of premiums }\end{array}$ \\
\hline $\begin{array}{l}\text { Alberts \& } \\
\text { Varaiya (1989) }\end{array}$ & & & & & $\checkmark$ & & $\checkmark$ \\
\hline Berman (1984) & & & $\checkmark$ & $\checkmark$ & & $\checkmark$ & \\
\hline $\begin{array}{l}\text { Campbell \& } \\
\text { Goold (1998) }\end{array}$ & $\checkmark$ & & & & & & $\checkmark$ \\
\hline $\begin{array}{l}\text { Choi \& } \\
\text { Philippatos } \\
(1983) \\
\end{array}$ & & & & & $\checkmark$ & & \\
\hline $\begin{array}{l}\text { Copeland, } \\
\text { Koller \& } \\
\text { Murrin (1990) }\end{array}$ & & & & $\checkmark$ & $\checkmark$ & & \\
\hline $\begin{array}{l}\text { Eccles, Lane \& } \\
\text { Wilson (1999) }\end{array}$ & & & & $\checkmark$ & $\checkmark$ & & \\
\hline $\begin{array}{l}\text { Galpin \& } \\
\text { Herndon (1999) }\end{array}$ & & & & & & & $\checkmark$ \\
\hline $\begin{array}{l}\text { Golbe \& White } \\
\text { (1978) }\end{array}$ & & & $\checkmark$ & $\checkmark$ & $\checkmark$ & $\checkmark$ & \\
\hline $\begin{array}{l}\text { Haspeslagh \& } \\
\text { Jemison (1991) }\end{array}$ & & & & & & & $\checkmark$ \\
\hline Lajoux (1997) & & & & & & & $\checkmark$ \\
\hline $\begin{array}{l}\text { Magenheim \& } \\
\text { Mueller (1988) }\end{array}$ & & & & $\checkmark$ & $\checkmark$ & & \\
\hline $\begin{array}{l}\text { Marks \& } \\
\text { Mirvis (1997) }\end{array}$ & $\checkmark$ & & & & $\checkmark$ & & $\checkmark$ \\
\hline $\begin{array}{l}\text { Rappaport } \\
(1998)\end{array}$ & & $\checkmark$ & & $\checkmark$ & $\checkmark$ & $\checkmark$ & $\checkmark$ \\
\hline Sirower (1997) & $\checkmark$ & $\checkmark$ & $\checkmark$ & $\checkmark$ & $\checkmark$ & $\checkmark$ & $\checkmark$ \\
\hline $\begin{array}{l}\text { Slusky \& } \\
\text { Caves (1991) }\end{array}$ & & & & & & & $\checkmark$ \\
\hline Zweig (1995) & $\checkmark$ & & & & & & $\checkmark$ \\
\hline $\begin{array}{l}\text { Frequency } \\
\text { (out of a total } \\
\text { 16) }\end{array}$ & 4 & 2 & 3 & 7 & 9 & 4 & 10 \\
\hline
\end{tabular}

The research identified a common and fundamental misunderstanding among merger and acquisition executives. Ten of the sixteen authors indicated that many executives forget the present value considerations of paying a premium upfront in exchange for the opportunity to generate synergistic gains in the future. The future gains must be valued in the present time when compared to the premium as this can fundamentally affect the ultimate success of a transaction. Synergistic gains have to be realised as soon as possible after merger to ensure that value is also created for the buying shareholders. The next two most significant consequences of paying an acquisition premium are that the market punishes the acquirer for overpaying and, where the premium paid is higher than the anticipated value of the synergies, the sellers will capture all of the value created through the merger or acquisition. A proper evaluation of 
the synergies anticipated from the combination must be made in advance of any decision regarding payment of an acquisition premium as the two aspects are inextricably interlinked and the ultimate consequence of a failure to link them is a failure of the merger or acquisition.

\section{Potential value creation evaluation}

'The basic objective of making acquisitions is identical to any other investment associated with the company's overall strategy, namely, to add value' (Rappaport, 1998:138). Three broad techniques were identified from the literature for analysing the extent of the value creation potential and for ensuring that productive synergies were realised. These can be summarised as follows:

a) An analysis of the extent of the acquisition premium to be paid versus the potential value creation opportunities. Sirower (1997) had performed extensive research into the extent to which the level of the premium can be used to predict the success or failure of the combination. The technique of comparing the premium (i.e. the cost) with the benefits (i.e. the synergies) can also be translated into other less pronounced costs and benefits and Marks \& Mirvis (1997) describe this process in terms of 'pains versus gains analysis'. Value creation through mergers and acquisitions can be seen as the residual value resulting from the 'gains' made from the combination less the 'pains' experienced i.e. the net inflows from the combination. Managing to create value requires attention at both ends of the equation - the gains need to be maximised and the pains minimised (Marks \& Mirvis, 1997). Alberts and Varaiya (1989) and Eccles, Lane and Wilson (1999) also look at this technique.

b) Rappaport's (1998) Shareholder Value Added (SVA) methodology epitomises the second category of analysis techniques. According to this grouping, the extent of actual shareholder value to be added through a combination is the only true measure of the success or failure of the merger or acquisition. Competitive advantage is a foundational building block of synergistic gains and the long-term gains to shareholders from these strategies can be estimated by the existence of competitive advantages. Identifying and valuing these strategies enables management to identify and pursue these sources of value creation. Campbell and Goold (1998) and Shleifer and Vishny (1988) also investigate this technique.

c) The third type of approach is a process-directed technique. Authors advocating this technique focus on the processes of the acquisition such as integration, decision making and transfer of capabilities that generate productive synergies. For example, Lajoux (1997) focuses exclusively on the plans to integrate and implement the transaction whereas Haspeslagh and Jemison (1991) concentrate on the process for achieving a successful transfer of capabilities. Eienhardt and Galunic (2000), Fisher (1994) and
Galpin and Herndon (1999) also examine process issues.

Each of the three approaches identified from the literature adopted a procedure for the quantification and qualification of synergies at the outset and go on to evaluate the substantive achievement of productive synergies in the implementation stage.

\section{Resources and methodologies required for the achievement of productive synergies}

A study revealed that only $23 \%$ of mergers even cover the cost of the acquisition, not to mention achieving the levels of synergistic gains that are touted about a transaction (Fisher, 1994). If synergies provide the rationale for merger and acquisition activity, the best practices, strategies and considerations for achieving these synergies in practice must be identified and isolated. Nine predominant techniques and strategies for the creation and sustainability of synergies were identified from the literature. The relative significance of the various techniques is schematically represented in Table 3.

Adequate planning for the integration of the merger, establishing efficient and effective rewards systems and incentive mechanisms, and establishing the acquisition premium relative to the anticipated synergies appear to be the most significant techniques and strategies for successful mergers and acquisitions. Notwithstanding this relative significance, there is a generally high occurrence of each technique, and all must, therefore, be regarded as substantially important in the realisation of productive synergies through mergers and acquisitions.

\section{Synergy evaluation model}

The purpose of this analysis was to distil these findings into a process model. The Value Creation through Synergy Evaluation Model, shown in Figure 1, incorporates the most significant findings from the research into a single model and provides a framework from which the merger and acquisition process can be better managed and understood. The best practices identified from the literature in this study have motivated their inclusion in various stages in the process.

Checkpoints have been inserted in the process to serve as checks and balances for the executive involved in a merger or an acquisition so that there is some objective measure to prevent the emotions of a combination transaction driving the process as opposed to the fundamentals identified in this research. The checkpoints should force managers to check whether the numbers add up and to put them in a position to abort the transaction and thus not to persist with a value destroying acquisition. 
Table 3: Techniques for generating productive synergies

\begin{tabular}{|c|c|c|c|c|c|c|c|c|c|}
\hline & $\begin{array}{l}\text { Post- } \\
\text { merger } \\
\text { inte- } \\
\text { gration } \\
\text { plan }\end{array}$ & $\begin{array}{c}\text { Acquire } \\
\text { and retain } \\
\text { superior } \\
\text { merger } \\
\text { manage- } \\
\text { ment and } \\
\text { executive } \\
\text { leadership }\end{array}$ & $\begin{array}{c}\text { Perform } \\
\text { a } \\
\text { compre- } \\
\text { hensive } \\
\text { due } \\
\text { diligence } \\
\text { in } \\
\text { advance - } \\
\text { i.e. buy } \\
\text { the right } \\
\text { company }\end{array}$ & $\begin{array}{c}\text { Perform } \\
\text { advanced } \\
\text { planning } \\
\text { and } \\
\text { provide for } \\
\text { substantial } \\
\text { manage- } \\
\text { ment of the } \\
\text { integration } \\
\text { process }\end{array}$ & $\begin{array}{c}\text { Establish } \\
\text { efficient } \\
\text { rewards } \\
\text { and } \\
\text { incen- } \\
\text { tives }\end{array}$ & $\begin{array}{c}\text { Focus on } \\
\text { share- } \\
\text { holder } \\
\text { value } \\
\text { creation } \\
\text { and don't } \\
\text { do the } \\
\text { deal if the } \\
\text { numbers } \\
\text { don't add } \\
\text { up }\end{array}$ & $\begin{array}{l}\text { Relate the } \\
\text { premium } \\
\text { paid to the } \\
\text { expected } \\
\text { synergies }\end{array}$ & $\begin{array}{c}\text { Learn } \\
\text { from } \\
\text { your mis- } \\
\text { takes and } \\
\text { commun- } \\
\text { icate } \\
\text { effect- } \\
\text { ively }\end{array}$ & $\begin{array}{c}\text { Apply a } \\
\text { broad } \\
\text { base of } \\
\text { ordinary } \\
\text { manage- } \\
\text { ment } \\
\text { principles }\end{array}$ \\
\hline $\begin{array}{l}\text { Alberts \& } \\
\text { Segall (1974) }\end{array}$ & & & $\checkmark$ & & & & & $\checkmark$ & $\checkmark$ \\
\hline $\begin{array}{l}\text { Alberts \& } \\
\text { Varaiya } \\
(1989) \\
\end{array}$ & & & & & & $\checkmark$ & $\checkmark$ & & \\
\hline $\begin{array}{l}\text { Anslinger \& } \\
\text { Copeland } \\
(1996)\end{array}$ & & $\checkmark$ & & $\checkmark$ & $\checkmark$ & & & & $\checkmark$ \\
\hline $\begin{array}{l}\text { Campbell \& } \\
\text { Goold (1998) }\end{array}$ & & & & & $\checkmark$ & $\checkmark$ & & & $\checkmark$ \\
\hline $\begin{array}{l}\text { Eccles, Lane } \\
\text { \& Wilson } \\
(1999)\end{array}$ & & & & & & $\checkmark$ & $\checkmark$ & & \\
\hline $\begin{array}{l}\text { Eienhardt \& } \\
\text { Galunic } \\
(2000)\end{array}$ & & & & & $\checkmark$ & & & & \\
\hline Fisher 1994 & $\checkmark$ & $\checkmark$ & $\checkmark$ & $\checkmark$ & & & & $\checkmark$ & \\
\hline $\begin{array}{l}\text { Galpin \& } \\
\text { Herndon } \\
\text { (1999) }\end{array}$ & $\checkmark$ & $\checkmark$ & $\checkmark$ & $\checkmark$ & $\checkmark$ & & & $\checkmark$ & $\checkmark$ \\
\hline $\begin{array}{l}\text { Haspeslagh \& } \\
\text { Jemison } \\
(1991)\end{array}$ & $\checkmark$ & $\checkmark$ & $\checkmark$ & $\checkmark$ & & & $\checkmark$ & $\checkmark$ & \\
\hline \multicolumn{10}{|l|}{ Howell (1970) } \\
\hline $\begin{array}{l}\text { Jemison \& } \\
\text { Sitkin (1986) } \\
\end{array}$ & $\checkmark$ & $\checkmark$ & & & $\checkmark$ & & & & \\
\hline Key (1989) & & & & & & & $\checkmark$ & & $\checkmark$ \\
\hline $\begin{array}{l}\text { Kitching } \\
(1967)\end{array}$ & $\checkmark$ & $\checkmark$ & & & $\checkmark$ & & & & \\
\hline Lajoux (1997) & $\checkmark$ & & & $\checkmark$ & & & $\checkmark$ & $\checkmark$ & \\
\hline $\begin{array}{l}\text { Marks \& } \\
\text { Mirvis (1997) }\end{array}$ & $\checkmark$ & $\checkmark$ & $\checkmark$ & $\checkmark$ & $\checkmark$ & & $\checkmark$ & & \\
\hline $\begin{array}{l}\text { Rappaport } \\
(1998)\end{array}$ & $\checkmark$ & & & & $\checkmark$ & $\checkmark$ & $\checkmark$ & & \\
\hline $\begin{array}{l}\text { Shleifer \& } \\
\text { Vishny (1988) }\end{array}$ & & & & & $\checkmark$ & & & & \\
\hline $\begin{array}{l}\text { Sirower } \\
(1997)\end{array}$ & & & & & & & $\checkmark$ & & \\
\hline $\begin{array}{l}\text { Staw \& Ross } \\
\text { (1987) }\end{array}$ & & & & & & $\checkmark$ & & & \\
\hline Zweig (1995) & $\checkmark$ & & & & & & $\checkmark$ & & \\
\hline $\begin{array}{l}\text { Frequency } \\
\text { (out of a total } \\
20)\end{array}$ & 9 & 7 & 5 & 6 & 9 & 5 & 9 & 5 & 5 \\
\hline
\end{tabular}




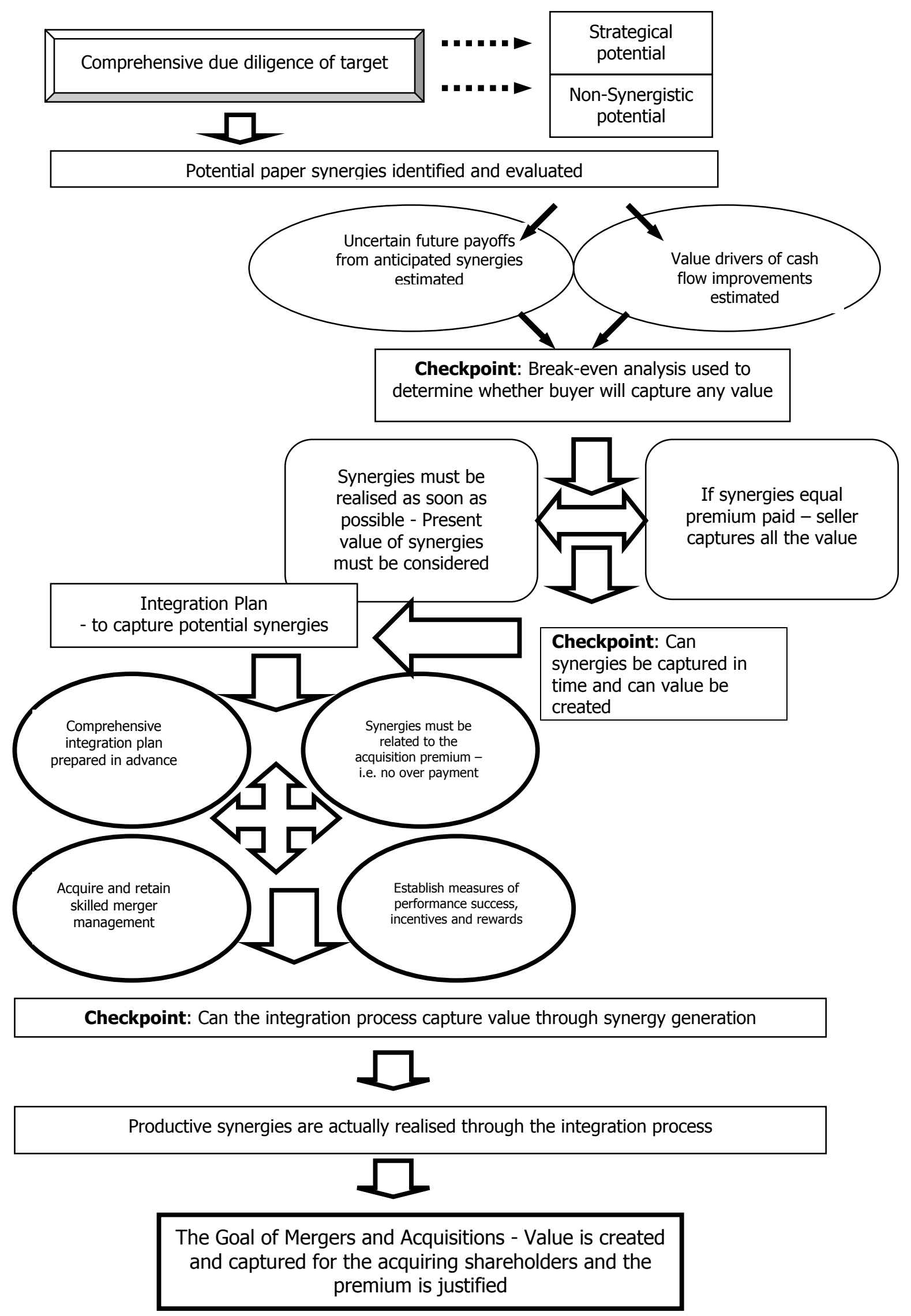

Figure 1: The value creation through synergy evaluation model 
The integrative model is a process model and follows a logical progression from initial analysis of the target company to the point when actual value is captured for the acquiring shareholders. The model, by definition, is a simplified manner of presenting complex and detailed information. Each stage of the process is a summary of many facts and sub-processes and managers involved in mergers and acquisitions must gain at least a basic understanding of the forces and factors involved in each stage before trying to apply the principles.

The model begins with the due diligence process to establish the synergistic potential. Mergers and acquisitions can only be motivated by reasons falling into one or a combination of these categories: (1) synergistic reasons, (2) non-synergistic reasons or (3) strategic reasons. The reasons for doing mergers and acquisitions, are all at least partially driven by synergies. For executive managers involved in mergers or acquisitions, there is, therefore, a high probability that synergies will at least be a partial reason driving the transaction and a failure to evaluate those synergistic opportunities adequately or at all, will severely undermine the chances of the combination succeeding.

Table 1 isolated the key reasons for the failings in mergers and acquisitions. Overpayment and the failure to integrate combinations properly were regarded as the most significant causes of unsuccessful mergers and acquisitions. Overpayment, or the payment of substantial premiums relative to the stand-alone value of the target company, is often justified through the extolment of valuable synergies to be achieved from merging. Even where the potential synergies are realisable and are correctly valued in the predeal stage, the failure to plan the cultural and process integration and/or to integrate adequately the combination will necessarily result in an inability to generate productive synergies. Therefore, in either event, there will be a destruction of shareholder value through the payment of a fixed cash sum to the seller's shareholders for no added value from synergies.

Although the results of the analysis into the extent to which synergy evaluation is treated as a distinct and separate stage in the merger and acquisition process were not definitive, the literature emphasises the importance of integration in the achievement of productive synergies. The two most popular approaches involved either a concentrated focus on the integration of synergies throughout the process or involved a holistic focus on the evaluation and attainment of synergies as the basis for the entire process. The authors advocating either of these two approaches all emphasised the crucial significance of synergy evaluation in the pre-deal stage and the relative support for these two approaches is indicative of the role that the evaluation of synergies plays in successful mergers and acquisitions. Synergy evaluation is thus vital for an understanding of what needs to be integrated and how that integration needs to take place so that productive synergies can be realised and shareholder value created through the merger and acquisition process.

The middle part of the model contrasts the value of the anticipated potential synergies with the acquisition premium. This part isolates the aspects highlighted in the study as being significant with respect to the justification of acquisition premiums by means of the evaluation of synergistic opportunities.

The analysis has shown a clear relationship between the value of the anticipated potential synergies and the amount of the acquisition premium paid. All authors included in the study into this issue related the acquisition premium to a consideration of the present value of the potential synergies. The left side circle in the model indicates an alternative approach to comparing the anticipated synergies with the premium. Notwithstanding this relationship, the evaluation of synergies is not simple: the process of relating the synergies to the purchase price is difficult. Substantial techniques and strategies are required on the part of executives and their advisors to capture the essence of the potential synergies in financial terms.

Since most mergers and acquisitions destroy shareholder value, there seems to be a substantial mismatch of the predeal expectations for synergies and the ultimate realisation of those synergies in practice. The mismatch arises from the unlikelihood of these companies achieving the performance improvements required to generate synergies beyond the normal operational requirements of the firms had they remained separate.

A common approach to achieving these performance improvements was through identification of the value drivers of the synergies and extrapolating the increased cash flows into a discounted cash flow model. Direct valuations of the various aspects of the synergies could then be made and compared with the proposed purchase price. The right side circle in the model indicates this alternative approach to comparing the anticipated synergies with the premium. This approach has an intuitive logic to it and it does serve a useful function. The direct cash flow valuation approach is however subject to the same type of manipulation as all discounted cash flow valuations. Key driving variables can be changed slightly with minimal justification and the result can be substantially altered to suit the result sought. Notwithstanding this downside, this approach can substantially support the other techniques and strategies used by the decision makers in the merger and acquisition process if the approach is used as an aid and not as a conclusive methodology on its own.

The break-even analysis checkpoint provides the executive involved in a merger or an acquisition with a point to reassess the continued pursuit of the target. Where the numbers do not add up, the process can be re-assessed and/or abandoned at that point. Sirower (1997) and Rappaport (1998) provided the most thorough analysis of the break-even formula, which they regarded as the fundamentals of the acquisition problem.

The formulae prescribed for the comparison of the potential synergies with the acquisition premium should be used to evaluate the synergies and determine whether any value will be created for shareholders of the buyer. These two considerations are represented as a dynamic interchange in the process of evaluating the synergies and also provide a checkpoint for management to arrest the process. 
Unfamiliarity with the fact that the net present value created for the buying shareholders is the difference between the synergies ultimately realised and the premium paid, is cited as the primary reason that so many senior executives are destroying shareholder value for their companies and shareholders (Sirower, 1997).

To create value, an estimation of the value-creating potential of the target must be made and this requires an initial assessment of the stand-alone value of the target, the acquisition benefits to be gained and the likely purchase price (Rappaport, 1998). This value created by the acquisition is the total value created by the acquisition and does not distinguish or apportion value to either the buyer's or the seller's shareholders. This apportionment is only determined in relation to the ultimate purchase price paid. The greater the premium paid, the greater is the amount of the value created by the acquisition that goes to the shareholder's of the target and the more difficult it becomes for the buyer to achieve acceptable rates of return from their investment (Rappaport, 1998). If the actual maximum acceptable purchase price is, in fact, paid, then the entire amount of value created by the acquisition will accrue to the shareholders of the target (Rappaport, 1998). Where the buyer has a distinctive ability to generate synergies and therefore value for shareholders, the value created for the buyer in this formula is more likely and since no other potential acquirer can create this value, this value is captured for the buyer's shareholders (Rappaport, 1998).

The lower part of the model, as represented, was developed from the techniques and strategies identified in the literature review as being significant means of achieving productive synergies from mergers and acquisitions in the integration phase.

Nine techniques and strategies for the creation of shareholder value through mergers and acquisitions were identified from the writings of the authors under review as being important in the merger and acquisition process. Although there were some that stood out because they were referred to more often than others, all were significant in the greater pursuit of productive synergies and should therefore all be viewed as crucial aspects of the merger and acquisition process.

Pre-deal planning (including a thorough due diligence investigation of 'hard' and 'soft' aspects of the target) and integration planning were highlighted as techniques to ensure the realisation of productive synergies. These two aspects were also identified in the section on the reasons for the failure of mergers and acquisitions and its central role with respect to synergies in mergers and acquisitions is accordingly emphasised. Two other significant techniques, namely the acquisition and retention of skilled merger management and the establishment of measures of performance success, incentives and rewards, were included in the integration stage. Horwitz et al (2002) provides a useful human resource model for managing culture during mergers and acquisitions. It is through the use of these techniques, and others identified but not specifically noted in the model, that potential synergies can be converted to productive synergies and value created for the acquiring shareholders.

Three additional issues were identified during the research for techniques and strategies for the generation of productive synergies. These issue were not included in the evaluation of the other techniques and strategies because of a lack of broad based support for them. They do, however, each have a substantial intuitive logic to them and demonstrate profound insights into the techniques required for the generation of productive synergies.

Firstly, Anslinger and Copeland (1996) identified that the existence of innovative operating strategies in mergers and acquisitions was the single largest source of value creation in successful acquisitions, whereas most authors focussed on the conventional drivers of synergistic gains i.e. financial leverage, market timing and industry selection. This research has shown that many combinations fail because of a failure to evaluate synergies adequately or at all. An adequate evaluation of synergies has been shown to require the identification of synergistic opportunities, pre-deal planning for the realisation of synergies and the evaluation of the relationship between the potential synergies and the acquisition premium. Where innovative operating strategies have been identified in the pre-deal stage of a combination, all three of these aspects of synergy evaluation would necessarily have been dealt with.

Secondly, Haspeslagh and Jemison (1991) identified the key difference between success and failure in mergers and acquisitions as being the existence of a superior understanding of the decision-making process. Decisionmaking is required from the pre-deal negotiations right through to the post-acquisition integration process. If executives involved in the transaction focus on the decisionmaking processes and management of those processes, substantial uncertainty can be removed from the synergy generation process. A number of the previously identified critical success factors in the evaluation of synergies involve strategic decision-making at key points in the process. If the decision-making process is managed with a view to the generation of productive synergies, many of the aspects highlighted before will fall into place.

Thirdly, Marks and Mirvis (1997) have isolated an unhealthy focus by executives on the financial implications of mergers and acquisitions. The causes for this were identified as the fact that most of the executives and their advisors were from financial positions or backgrounds and the 'hard' issues tended to take precedence over the 'soft' issues. In successful mergers and acquisitions on the other hand, executives applied a strategic mindset to the deal and clearly identified synergies in advance and developed a strategy for extracting those synergies prior to the negotiations reaching any meaningful stage. Many of the techniques and strategies identified by Horwitz et al (2002) and Bijlsma-Frankema (2001) are mechanisms for financially orientated executives to broaden their focus to the substantive issues of the evaluation of synergies. If executives were to adopt the techniques and strategies already identified, they would, in effect, be focussing on the soft and more real issues relating to synergies. Synergy 
evaluation is not solely a hard financial issue and attempts to treat it as such often result in failure.

\section{Conclusion}

The suggested future research agenda should include:

- An empirical study into the methodologies for quantifying synergistic opportunities and applying the synergy formulas;

- Case studies or time period studies of some of the techniques for the generation of productive synergies identified in this research; and

- A study of the various types of synergistic opportunities available through mergers and acquisitions and the value creation potential of each type

The model provides managers with numerous considerations and techniques for assessing the objective merits of a particular transaction. The model does highlight each of the most crucial aspects that must be considered in a successful merger or acquisition and for the generation of shareholder value through synergies. Executives involved in implementing synergistic mergers need to pay attention to each of the phases in the model. In particular they need to use the three checkpoints as opportunities to halt mergers and acquisitions that are unlikely to create value successfully beyond the acquisition premium. It is hoped that the application of this framework will help to limit the failure rate and increase the value created from synergies in mergers and acquisitions.

\section{References}

Alberts, W. W. \& Segall, J. E. (Eds.). 1974. The corporate merger. Chicago: University of Chicago Press.

Alberts, W. W. \& Varaiya, N. P. 1989. 'Assessing the profitability of growth by acquisition: A 'Premium Recapture' approach', International Journal of Industrial Organisation, 7:133-149.

Anslinger, P. L. \& Copeland, T. E. 1996. 'Growth through acquisitions: A fresh look', Harvard Business Review, (January-February):126-135.

Babbie, E. 1998. The practice of social research. Eight Edition, California: Wadsworth Publishing Company.

Bailey, K. D. 1982. Methods of social research. Second Edition. New York: The Free Press.

Berman, P. 1984. 'When someone says synergy, feel for your wallet', Forbes, December 3:38-39.

Bijlsma-Frankema, K. 2001. 'On managing cultural integration and cultural change processes in mergers and acquisitions', Journal of European Industrial Training, 25(2/3/4):192-207.
Buffett, W. 1982. Berkshire Hathaway Annual Report. Texas: Berkshire Hathaway.

Campbell, A. \& Goold, M. 1998. Synergy: Why links between business units often fail and how to make them work. Oxford: Capstone Publishing Limited.

Choi, D., \& Philippatos, G. C. 1983. 'An examination of merger synergism', Journal of Financial Research 6:239256.

Copeland, T., Koller, T. \& Murrin, J. 1990. Valuation Measuring and managing the value of companies. New York: John Wiley \& Sons.

Eccles, R. G., Lane, K. L. \& Wilson, T. C. 1999. 'Are you paying too much for that acquisition?', Harvard Business Review, (July-August):136-146.

Economist, The, July 22, 2000:17. How mergers go wrong.

Eienhardt, K. M. \& Galunic, D. C. 2000. 'Coevolving: At last, a way to make synergies work', Harvard Business Review. 78(1): 91-101.

Fisher, A. B. 1994. 'How to make a merger work,' Fortune, January 24:66-69.

Galpin, T. J. \& Herndon, M. 1999. The complete guide to mergers and acquisitions - Process tools to support $M \& A$ integration at every level. San Francisco: Jossey-Bass Inc.

Golbe, D. L. \& White, L. J. 1978. 'It's good logic, but is it good business?’ Forbes, November 13:138-140.

Groebner, D. \& Shannon, P. 1985. Business statistics: A decision making approach. Columbus, Ohio: Merril Publishing Company.

Haspeslagh, P. C. \& Jemison, D. B. 1991. Managing acquisitions - Creating value through corporate renewal. New York: The Free Press.

Haunschild, P. R. 1994. 'How much is that company worth? Inter-organisational relationships, uncertainty, and acquisition premiums,' Administrative Science Quarterly, 39:391-411.

Healy, P., Palepu, K. \& Ruback, R. S. 1992. 'Do mergers improve corporate performance?' Journal of Financial Economics, 31:135-175.

Howell, R. A. 1970. 'Plan to integrate your acquisitions', Harvard Business Review, (November - December): 66-76.

Horwitz, F. M, Anderssen, K, Bezuidenhout, A, Cohen, S, Kirsten, F, Mosoeunyane, K, Smith, N, Thole, K, \& Van Heerden, A. 2002. 'Due diligence neglected: Managing human resources and organisational culture in mergers and acquisitions', SA Journal of Business Management, 33(1):110. 
Jemison, D. B. \& Sitkin, S. B. 1986. 'Acquisitions: The process can be a problem', Harvard Business Review, (March-April):107-116.

Key, S. L. (Ed.). 1989. The Ernst \& Young management guide to mergers and acquisitions. New York: John Wiley \& Sons.

Kitching, J. 1967. 'Why do mergers miscarry?' Harvard Business Review, (November-December):84-101.

Lajoux, A. R. 1997. The art of $M \& A$ integration $-A$ guide to merging resources, processes and responsibilities. Washington, D.C: McGraw-Hill.

Magenheim, E. B. \& Mueller, D. C. 1988. 'Are acquiringfirm shareholders better off after an acquisition?' In Coffee, J.C., Lowenstein, L. \& Rose-Ackerman, S. (Eds.). Knights, raiders, and targets: The impact of hostile takeovers. New York: Oxford University Press, pp.171-193.

Marks, M. L. \& Mirvis, P. H. 1997. Joining forces - Making one plus one equal three in mergers, acquisitions and alliances. San Francisco: Jossey-Bass Inc.

Miles, M. \& Humberman, A. 1994. Qualitative data analysis. Second Edition. Thousand Oaks, California: Sage Publications Inc.

Rappaport, A. 1998. Creating shareholder value - A guide for managers and investors. New York: The Free Press.

Seyhun, N. 1990. 'Do bidder managers knowingly pay too much for target firms?' Journal of Business, 63:439-464.

Shleifer, A., \& Vishny, R. W. 1988. 'Value maximisation and the acquisition process,' Journal of Economic Perspectives, 2:7-20.

Sirower, M. 1997. How companies lose the acquisition game - The synergy trap. New York: The Free Press.

Slusky, A. R. \& Caves, R. E. 1991. 'Synergy, agency, and the determinants of premia paid in mergers,' Journal of Industrial Economics, 39:277-296.

Staw, B. M., \& Ross, J. 1987. 'Knowing when to pull the plug,' Harvard Business Review, (March-April):68-74.

Varaiya, N. P. 1987. 'Determinants of premiums in acquisition transaction,' Managerial and Decision Economics, 8:175-184.

Walker, R. (Ed.). 1985. Applied qualitative research. Hants: Gower.

Zikmund, W. G. 1997. Business research methods. Fifth Edition. Orlando: The Dryden Press.

Zweig, P. L. 1995. 'The case against mergers,' Business Week Special Report, October:122-130. 